\title{
UNDERSTANDING STUDENTS' POSITIVE EMOTIONS THROUGH PHOTOVOICE STUDY
}

\author{
Ahmad Muhammad Diponegoro, Agungbudiprabowo, Siti Muyana, Dian \\ Ari Widyastuti* \\ *Correspondent Author
}

Ahmad Muhammad Diponegoro Program Studi Magister Psikologi Universitas Ahmad Dahlan Jalan Pramuka Nomor 42, Umbulharjo, Yogyakarta, Indonesia

Emal: ahmad.diponegoro@psy.uad.ac.id

Agungbudiprabowo

Program Studi Bimbingan dan Konseling

Universitas Ahmad Dahlan

Jalan Ringroad Selatan, Tamanan,

Banguntapan, Bantul, Yogyakarta,

Indonesia

Email: agungbudiprabowo@bk.uad.ac.id

Siti Muyana

Program Studi Bimbingan dan Konseling

Universitas Ahmad Dahlan

Jalan Ringroad Selatan, Tamanan,

Banguntapan, Bantul, Yogyakarta

Indonesia

Email: siti.muyana@bk.uad.ac.id

Dian Ari Widyastuti

Program Studi Bimbingan dan Konseling

Universitas Ahmad Dahlan

Jalan Ringroad Selatan, Tamanan,

Banguntapan, Bantul, Yogyakarta,

Indonesia

Email: dian.widyastuti@bk.uad.ac.id

Page

98-106

\section{INTRODUCTION}

Inquiry into positive emotions such as compassion, love, awe, gratitude, and grace has improved promptly in recent years. The past decade has seen a large increase in emotion research on the subjective experience of distinct positive emotions. Whereas the majority of emotion research before the end of 20th century focused on general positive affect or mood (Desmet, 2015), in recent years affective scientists have increasingly shifted their attention to distinct emotional states. Groundbreaking pioneering, cutting edge, revolutionary, innovative studies have investigated numerous various individual positive emotions, love (O'Neill, 2017), awe (e.g., Gordon et al., 2017), tenderness (Buckels, et al., 2018), gratitude (Williams \& Bartlett, 2015),compassion (e.g., Lupoli, et al., 2017), pride (Weidman, et al., 2016), interest (Sung \& Yih, 2016), and admiration (e.g., Schindler, et al., 2015). Reflecting this trend, more than half decade ago the Handbook of Positive Emotions 
(Tugade, et al., 2014) dedicated more than seven chapters to one distinct positive emotion each. Furthermore, a quantitative review of articles published in the first decade of this century in the journal Emotion identified studies examining more than 30 distinct positive states (Weidman, et al., 2017).

Various studies on undergraduate students and their learning activities have been carried out. The methods that researchers have recently used to study undergraduate students were qualitative (Hill, et al., 2020; Villa, et al., 2020) and quantitative methods (Pham \& Lui, 2020), for example regulatory emotions (Hannan \& Orcutt., 2020). These variables include, the use of coping strategies, emotions, support, locus of control, mindfulness, and empathy (Killian, 2008; Thomas \& Otis., 2010).

The research applying photovoice method which express emotion were abundant. But none of those research put positive emotion into their research questions. Most research take participant from the secular world view (Cuthbert et al., 2018)

Religion plays an important role in psychological research and counseling. Because various studies show that religion can reduce acute stress (Farias \& Newheiser, 2019). Religion also enhances positive emotion such as gratitude and love (Krause \& Hayward, 2015). Research on Islam can be divided into qualitative and quantitative research. Qualitative research, for example, is related to the events of 9 September (AbuRas et al., 2013; Elkonin., 2014) and quantitative, for example, regarding the validation of religious instruments (Chen et al., 2020; Lee et al., 2013; Aghababaei et al., 2018)

However research that is religiously homogeneous participants using the photovoice method is still understudied. Likewise, universities affiliated with certain religions, specifically Islamic universities are still rarely studied. Research on students generally carried out in universities were not affiliated with any particular religion. For example, research on Saudi students in the United States (Yakaboski, et al., 2018). Research conducted on undergraduate students in Canada on five religions with the same measurement tool (Zafar \& Ross, 2015).

To address these gaps, photovoice-a community-based participatory action research method-was piloted at Guidance and counseling department Ahmad Dahlan university. This article is intended to provide information regarding the positive emotions as consequences of learning activities in Ahmad Dahlan University as well as to highlight the usefulness of the photovoice tool as a narrative intervention for muslims' students. Photovoice's three original purposes include:

(a) documenting the participant's strengths; (b) promote dialogue and understanding on major issues in the community; (c) communicate the ideas of community members to the general public (Wang and Burris, 1994, 1997). Scientific literature describes photovoice as a participatory action research method in which participants use cameras to take photographs of persons, contexts, or situations they consider representative of a particular aspect of their individual and/or social life (Harley, 2012; Sutton-Brown, 2014).

The university in this research has unique characteristics. Students are required to take courses related to Islam. Students must pass Islamic courses to be able to complete their education. Photovoice method will reveal the positive emotions of undergraduate students at a religious private university in Yogyakarta Indonesia. The results of this study can be a reference for counselors to help students understand their positive emotions through the photovoice method.

\section{METHODOLOGY}

In recruiting photovoice participants The selection criterion was the undergraduate's field of study, from guidance and counseling department. To participate in our photovoice project, 15 students between 19 and 23 years of age of whom 12 were females and 3 were males, were selected. Participation was voluntary, and the subjects were allowed to withdraw from the project at any time. Data collection in photovoice studies is an ongoing process that occurs over an extended period of time. Participants were given the option of 


\section{0 | PSIKOPEDAGOGIA}

JURNAL BIMBINGAN DAN KONSELING

Vol.9, No.2, December 2020

having their names associated with the photos or kept confidential (i.e., known only to a few members of the research team). The questions research for the students are as follows: "What do you See in this picture? What do you feel when you see this picture? How does this relate to your lives? (modified from Wang, 1999, p. 188).

\section{RESULT AND DISCUSSION}

Three mains themes were found from the students' pictures. Several building pictures as places to learn and gaining support see figure 1, learning activities see figure 2 the prayer mat, and leisure. These places were comfortable places for them to study and seek knowledge see figure 1 , with the support of modern facilities
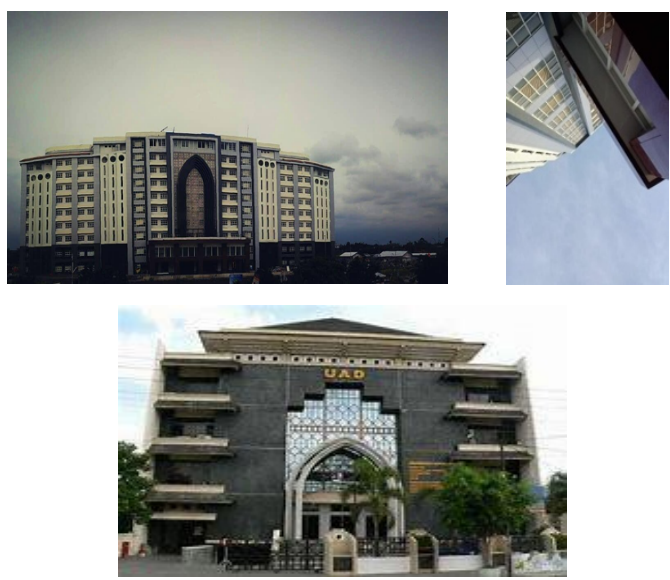

Figure 1.

Building

FST a female wrote

This is where I study and meet friends. I feel happy to get together and share stories and lessons with them.

This statement revealed that the place and peer support to make FST happy, one of the ancient positive emotion.

$\mathrm{PN}$ a female student wrote in her narratives:

This building is a witness that I am serious about learning. Apart from the knowledge that I got, I also gained experience and friends.

SP a female student commented in her picture:

It was in this place (campus 2) that I first sought knowledge before in the end my study program was transferred to campus 4. In this place I found new friends who were also in my study program. At that time $P 2 K, \quad I$ felt confused because I came from outside Java Island so I didn't know anyone. But unlike what I imagined, the friends who were there were very kind, and accepted anyone to be friends with.

YAW a female student reported

This is where I seek knowledge to achieve my dreams. In the past, you still use stairs, now you use the escalator

DFN is a female student wrote in her picture This is the campus where I studied, namely the Ahmad Dahlan University campus. I study at this campus and InshaaAllah will soon finish my studies well. For 8 semesters I have studied at this campus, and this campus will make sweet memories of my youth in achieving my dreams.

DS is a female student wrote

It is in this place that I look for sustenance, divide my time between work, continue my studies and worship. When I feel tired, I always come to read books.
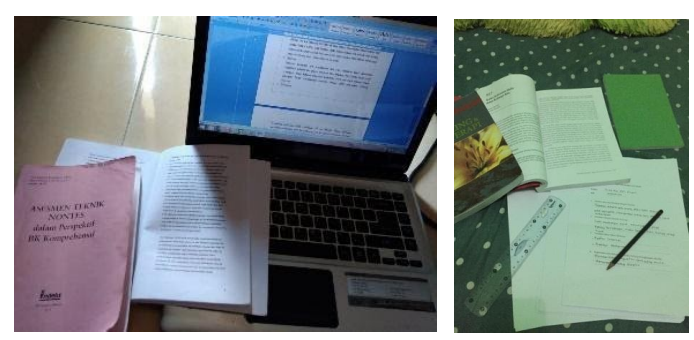

Figure 2.

Learning

YAW female student said Apart from being busy with the organization I am also always busy with college assignments and almost every day there is always a lecture assignment. Full of enthusiasm in doing tasks even though the body feels tired.

SS female student said

I feel depressed and tired when there are many assignments given by the lecturer, not just one course but for each course there is a task that must always be done.

FST female student said

So many tasks given sometimes make me tired because I have to struggle with the monitor screen for a long time. However, all of 
that is my responsibility that I have to do as a student.

This image represents them apart from having to carry out their daily activities, and being preoccupied with their many assignments and also not forgetting to always worship Allah SWT. Because of all the sadness, fatigue and also fatigue after doing the business of the day, just by worshiping will get calm and also peace. In fact, sometimes the answers to all the difficulties of our life will be found by doing worship. Like the comments they have put forward.

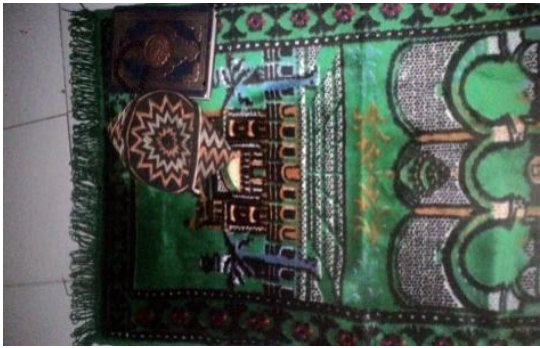

Figure 3.

Religion

CE a female student said she keep begging to Alloh for happy life.

In this prayer mat, I am always pray and beg for my happy life.

Emotional feelings: Happy, Sad, Grateful

EL, also a female student wrote

because of my busy schedule on campus and in organizations, sometimes I find it difficult to manage time between organizing, doing college assignments and praying to Allah SWT.

AAA is a female student wrote

This is my favorite prayer mat, which I use to perform worship and tell my problems to Allah SWT.

Emotions: love and serenity

ADS, a male student wrote

The prayer mat is a very noble object for Muslims, but not everyone touches this object. Lately, he has been negligent in carrying out his prayers. But I still took the time to worship and pray to Allah SWT

$\mathrm{PN}$ is a female student wrote

When my time is always spent doing assignments, I feel sad because my prayer time is cut off. And I always pray to Allah SWT so that health is always given and give me patience in living every life. 0

For me, worship is a necessity, not an obligation. If we feel it is necessary, then we will do it sincerely, but it will seem forced if it is an obligation.

Although EL was busy, EL tried to fulfill his obligation toward Allah and friends.

Because of my busy life do on campus and at organization sometimes I find it difficult to manage time between organizing, doing college assignments and worship Allah SWT AA

This is my favorite prayer mat, which I use to perform prayer services and tell stories about my problems to Allah SWT.

Emotions: love, love, calm

CE

Prayer mate

In this prayer mat, I always beg and ask to Allah to make my life happy.

Feelings of emotions: Happy, Sad, Grateful ADS

The prayer mat is a very noble object for Muslims, but not everyone touches this object. Recently, he has been negligent in performing his prayers. But I still took the time to worship and pray to Allah SWT

$\mathrm{PN}$ informed, through Figure 4, that he needed to worship Allah. this sincere

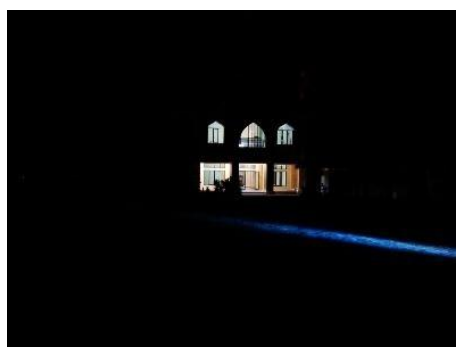

Figure 4.

Mosque

For me, worship is a necessity not an obligation. If we feel that our prayer is a need, then we will do it sincerely, but it will seem forced if it is an obligation.

SS was sad when her prayer time was interrupted. she prayed may Allah may God grant him health She wrote:

When my time is always spent doing assignments, I feel sad that my prayer time is interrupted. And I always pray to Allah SWT 


\section{2 | PSIKOPEDAGOGIA}

JURNAL BIMBINGAN DAN KONSELING

Vol.9, No.2, December 2020

so that health is always given and given me patience in living every life.

There were several positive emotions in the students narratives. Happy, grateful, and some negative emotions as sad, tired. This article aimed to widen the use of photovoice in education and especially in learning research. The results showed that for some students worship needs to be displayed in the pictures they take and is an important thing besides studying. For example that is disclosed. But this does not mean that students who did not present images related to worship did not know anything about Islam. The interview revealed that. all the participants took courses related to Islam. All participants are able to read the Quran and recite the Quran more than once a week. From the students writings we conclude that there was relationship between religiosity and resilience (Kaplick \& Skinner, 2017; Hamby, et al., 2017).

Students express a lot of happy feelings. The support they get from friends also supports their learning activities. As a positive psychological variable, support can improve their psychological state of positive emotion (Reife, et al., 2020). There was one student who attended the first time she felt isolated because he came from outside Java, which is a problem for teenagers. Friends who come from one religion, support and invite them to be friends, so his life becomes happier and supported. It was supported by previous finding (Corrigan et al., 2019). Happiness is an expression of the emotions of a number of students (Barker, et al., 2016; Speer, et al., 2014). Talk about student positive emotions that are more than negative emotions is the main study in positive psychology (Kim, Doiron, Warren, \& Donaldson, 2018). Sadness seems to be seen in one student emotion, but only one. Feeling sad is good for supporting positive emotion in specific way (Sharman, et al., 2019). Joy, the anger that appears to one of the students is actually one of the characteristics of achievement emotion (Huang, 2011; Pekrun, et al., 2017). But behind anger, it turns out that there was hope mixed with fear (Hill, et al., 2016). It turns out that Islam also motivates students to learn. This is in accordance with the findings of a previously published study (Fatima, Mehfooz, \& Sharif, 2017).

Positive emotions also provide effective outcomes by intensifying and building behavioral and psychological properties (eg, coping resources; Van Cappellen, 2016). In the university context, positive psychological states are associated with high perceptions of control (Goetz, et al., 2010), both of which have a strong relationship with mean grade (GPA; see meta-analysis by Richardson, et al., 2012). Thus, students who are able to accomplish their emotions can maintain a high level of positive influence over the course of university perhaps building up extensive psychological assets such as agency, while at the same time focusing these resources on specific tasks that will ultimately lead to to academic success.

However, positive psychological states alone may not tell the academic success. Although chronic experiences of negative emotions (for example, depressive symptoms, sadness, anger), when paired with low levels of positive emotions, can contribute to low academic performance (Bibi, et al, 2019), the negative affective experience can also change the cognitive scope (Harmon-Jones et al., 2013) For example, among adolescent girls, periods of negative influence led increased ability to set goals which in turn predicted improvements (Ayuso-Mateos, et al., 2010).

To defense this claim, the results of journal studies demonstrate that students who habitually experience positive and sometimes negative influences during the semester achieve the greatest academic success (Vimalanathan \& Babu, 2014). Likewise, students with student reports or profiles including high positive and negative influences are accomplishing the greatest academic success (Liu \& Wang, 2014). These results reflect the short-term association between affective experiences and academic success.

These findings support this research, particularly the frequent positive emotion (grace, awe, admiration, compassion - love, happy, grateful) and sometimes negative emotion (sad, tired, anger) experienced by 
students, will make students finish and complete their assignment successfully. In this study, it can be found in students with the initials CE and SP. Meanwhile, grateful students can be found in $\mathrm{CE}$ and $\mathrm{DNH}$ students. Although the students didn't mention awe, admiration and compassion or grace in their narrative, but it could be found in their quranic recitation and prayers.

Based on the results of this study, counselors can use the photovoice method to help students recognize their positive emotions. Photovoice is a promising method for understanding positive psychological variables of students as a tool for personal empowerment and transformation.

\section{CONCLUSIONS}

Almost half of the students showed the payer mat that they usually pray on it. The prayers were very important for them. It boost their positive emotion (for example admiration, awe, gratitude, and compassion). The positive emotion of admiration was found in their quranic recitation when their perform prayer. It was found admiration, grace and compassion in their prayer,

\section{ACKNOWLEDGMENT}

We feel so grateful to the department of guidance and counseling and department of psychology Ahmad dahlan University in supporting this research

\section{REFERENCE}

Abu-Ras, W., Senzai, F., \& Laird, L. (2013). American muslim physicians' experiences since 9/11: cultural trauma and the formation of Islamic identity. Traumatology, 19(1), 11-19. https://doi.org/10.1177/153476561244 1975

Aghababaei, N., Krauss, S. W., Aminikhoo, M., \& Isaak, S. L. (2018). The circumplex religious orientation inventory: validity and reliability of a new approach to religious orientation in a muslim population. Psychology of Religion and Spirituality, 11(4), 350357.

https://doi.org/10.1037/rel0000187
Ayuso-Mateos, J. L., Nuevo, R., Verdes, E., Naidoo, N., \& Chatterji, S. (2010). From depressive symptoms to depressive disorders: the relevance of thresholds. The British Journal of Psychiatry, 196(5), 365-371.

Barker, E. T., Howard, A. L., Galambos, N. L., \& Wrosch, C. (2016). Tracking affect and academic success across university: Happy students benefit from bouts of negative mood. DevelopmentalPsychology, 52( 12),20222030. https://doi.org/10.1037/ dev0000231

Bibi, A., Blackwell, S. E., \& Margraf, J. (2019). Mental health, suicidal ideation, and experience of bullying among university students in Pakistan. Journal of health psychology.

Buckels, E. E., Beall, A. T., Hofer, M. K., Lin, E. Y., Zhou, Z., \& Schaller, M. (2018). Individual differences in activation of the parental care motivational system: Assessment, prediction, and implications. Journal of Personality and Social Psychology, 108, 497-514. https://doi.org/10.1037/pspp0000023

Corrigan, P. W., Sheehan, L., Walley, G., Qin, S., Nieweglowski, K., \& Maurer, K. (2019). Strengths and challenges of peer coaches for supported education in colleges and universities. Psychiatric Rehabilitation

Journal. https://doi.org/10.1037/pri000 $\underline{0390}$

Cuthbert, A. D., Davis, E. B., Aten, J. D., Short, A., Andrew Yarborough, C., Lavelock, C. R., \& Van Tongeren, D. R. (2018). Cultivating humility in religious leaders: The effectiveness of a spiritually integrated positive psychology intervention. Spirituality in Clinical Practice, 5(4), 227-239. https://doi.org/10.1037/scp0000185

Desmet, P. M. (2015). Design for mood: Twenty activity-based opportunities to design for mood regulation. International Journal of Design, 9(2).

Elkonin, D., Brown, O., \& Naicker, S. (2014). Religion, spirituality and therapy: 


\section{4 | PSIKOPEDAGOGIA}

JURNAL BIMBINGAN DAN KONSELING

Vol.9, No.2, December 2020

Implications for training. Journal of religion and health, 53(1), 119-134.

Farias, M., \& Newheiser, A. K. (2019). The effects of belief in God and science on acute stress. Psychology of Consciousness: Theory Research, and Practice, 6(2), 214-223. https://doi.org/10.1037/cns0000185

Fatima, S., Mehfooz, M., \& Sharif, S. (2017). Role of Islamic religiosity in predicting academic motivation of university students. Psychology of Religion and Spirituality, 9(4), 377386. https://doi.org/10.1037/rel000009 $\underline{7}$

Goetz, T., Frenzel, A. $\quad$ C., Stoeger, H., \& Hall, N. C. (2010). Antecedents of everyday positive emotions: An experience sampling analysis. Motivation and Emotion, 34, 49-62. https://doi.org/10.1007/s11031009-9152-2

Gordon, A. M., Stellar, J. E., Anderson, C. L., McNeil, G. D., Loew, D., \& Keltner, D. (2017). The dark side of the sublime: Distinguishing a threat-based variant of awe. Journal of Personality and Social Psychology, 113, 310-328. https://doi.org/10.1037/pspp0000120

Hamby, S., Grych, J., \& Banyard, V. (2017). Resilience portfolios and polystrengths: Identifying protective factors associated with thriving after adversity. Psychology of Violence, 8(2), $172-$ 183. https://doi.org/10.1037/vio000013 $\underline{5}$

Hannan, S. M., \& Orcutt, H. K. (2020). Emotion regulation in undergraduate students with posttraumatic stress symptoms: A multimethod study. Psychological Trauma: Theory, Research, Practice, and Policy, 12(6), 643-650. http://dx.doi.org/10.1037/tra0000577

Harley, A. (2012). Picturing reality: Power, ethics and politics in using photovoice. International Journal of Qualitative Methods, 11, 320-339.

Harmon-Jones, E., Gable, P. A., \& Price, T. F. (2013). Does negative affect always narrow and positive affect always broaden the mind? Considering the influence of motivational intensity on cognitive scope. Current Directions in Psychological Science, 22, 301307. https://doi.org/10.1177/09637214 13481353

Hill, F., Mammarella, I. C., Devine, A., Caviola, S., Passolunghi, M. C., \& Szücs, D. (2016). Maths anxiety in primary and secondary school students: Gender differences, developmental changes and anxiety specificity. Learning and Individual Differences, 48, 45-53.

Hill, C. E., Anderson, T., Gerstenblith, J. A., Kline, K. V., Gooch, C. V., \& Melnick, A. (2020). A follow-up of undergraduate students five years after helping skills training. Journal of Counseling Psychology, 67(6), 697-705. http://dx.doi.org/10.1037/cou0000428.

Huang, C. (2011). Achievement goals and achievement emotions: A metaanalysis. Educational psychology review, 23(3), 359.

Kaplick, P. M., \& Skinner, R. (2017). The evolving Islam and Psychology movement. European Psychologist, 22(3), 198.

Krause, N., \& Hayward, R. D. (2015). Humility, compassion, and gratitude to God: Assessing the relationships among key religious virtues. Psychology of Religion and Spirituality, 7(3), 192-204. https://doi.org/10.1037/rel0000028

Lee, S. A., Reid, C. A., Short, S. D., Gibbons, J. A., Yeh, R., \& Campbell, M. L. (2013). Fear of Muslims: Psychometric evaluation of the Islamophobia Scale. Psychology of Religion and Spirituality, 5(3), 157-171. https://doi.org/10.1037/a0032117

Liu, Y., \& Wang, Z. (2014). Positive affect and cognitive control: Approach-motivation intensity influences the balance between cognitive flexibility and stability. Psychological Science, 25(5), 1116-1123.

Lupoli, M. J., Jampol, L., \& Oveis, C. (2017). Lying because we care: Compassion increases prosocial lying. Journal of 
Experimental Psychology: General, 146, 1026-1042. https://doi.org/10.1037/xge0000315

O'Neill, O. A., \& Rothbard, N. P. (2017). Is love all you need? The effects of emotional culture, suppression, and work-family conflict on firefighter risk-taking and health. Academy of Management Journal, 60(1), 78-108.

Pekrun, R., Lichtenfeld, S., Marsh, H. W., Murayama, K., \& Goetz, T. (2017). Achievement Emotions and Academic Performance: Longitudinal Models of Reciprocal Effects. Child Development, 88(5), 16531670. https://doi.org/10.1111/cdev.127 $\underline{04}$

Pham, S., \& Lui, P. P. (2020). Acculturation and alcohol use outcomes: Incremental roles of bicultural orientations among Asian American undergraduate and graduate students. Cultural Diversity and Ethnic Minority Psychology, 26(4), 483-497.

http://dx.doi.org/10.1037/cdp0000318)

Reife, I., Duffy, S., \& Grant, K. E. (2020). The Impact of Social Support on Adolescent Coping in the Context of Urban Poverty. 26(2), 200-214.

Richardson, M., Abraham, C., \& Bond, R. (2012). Psychological correlates of university students' academic performance: A systematic review and metaanalysis. Psychological Bulletin, 138, 353-

387. https://doi.org/10.1037/a0026838

Schindler, I., Paech, J., \& Löwenbrück, F. (2015). Linking admiration and adoration to self-expansion: Different ways to enhance one's potential. Cognition and Emotion, 29, 292-310. https://doi.org/10.1080/02699931.2014 .903230

Sharman, L. S., Dingle, G. A., Vingerhoets, A. J. J. M., \& Vanman, E. J. (2019). Using crying to cope: Physiological responses to stress following tears of sadness. Emotion. https://doi.org/10.1 $\underline{037 / \mathrm{emo} 0000633}$
Speer, M. E., Bhanji, J. P., \& Delgado, M. R. (2014). Savoring the past: Positive memories evoke value representations in the striatum. Neuron, 84(4), 847856. https://doi.org/10.1016/i.neuron.2 014.09 .028

Sung, B., \& Yih, J. (2016). Does interest broaden or narrow attentional scope? Cognition and Emotion, 30, 14851494.

https://doi.org/10.1080/02699931.2015 .1071241

Sutton-Brown, C. (2014). Photovoice: A methodological guide. Photography \& Culture, 7, 169-186.

Van Cappellen, P., Toth-Gauthier, M., Saroglou, V., \& Fredrickson, B. L. (2016). Religion and well-being: The mediating role of positive emotions. Journal of Happiness studies, 17(2), 485-505.

Villa, E. Q., Esquinca, A., Hampton, E., \& Guerra, H. M. (2020). "Is engineering for me?": Examining Latinas' narratives of resilience and agency to confront enduring struggles and challenges in undergraduate engineering studies. Peace and Conflict: Journal of Peace Psychology, 26(4), 403-413. http://dx.doi.org/10.1037/pac0000427)

Vimalanathan, K., \& Babu, T. R. (2014). The effect of indoor office environment on the work performance, health and wellbeing of office workers. Journal of environmental health science and engineering, 12(1), 1-8.

Tugade, M. M., Shiota, M. N., \& Kirby, L. D. (Eds.). (2014). Handbook of positive emotions. New York, NY: Guilford Press.

Wang, C. C. (1999). Photovoice: A participatory action research strategy applied to women's health. Journal of Women's Health, 8, 185192.participatory research for health. San Francisco: Jossey-Bass.

Wang, C., \& Burris, M. A. (1994). Empowerment through photo novella: Portraits of participation. Health Education Quarterly, 21, 171-186.

Wang, C., \& Burris, M. A. (1997). Photovoice: Concept, methodol- ogy, and use for 


\section{6| PSIKOPEDAGOGIA}

JURNAL BIMBINGAN DAN KONSELING

Vol.9, No.2, December 2020

participatory needs assessment. Health Education and Behavior, 24, 369-387.

Weidman, A. C., Steckler, C. M., \& Tracy, J. L. (2017). The jingle and jangle of emotion assessment: Imprecise measurement, casual scale usage, and conceptual fuzziness in emotion research. Emotion, 17, 267-295. https://doi.org/10.1037/emo0000226

Weidman, A. C., Tracy, J. L., \& Elliot, A. J. (2016). The benefits of following your pride: Authentic pride promotes achievement. Journal of Personality, 84 , 607-622. https://doi.org/10.1111/jopy.12184

Williams, L. A., \& Bartlett, M. Y. (2015). Warm thanks: Gratitude expression facilitates social affiliation in new relationships via perceived warmth. Emotion, 15, 1-5. https://doi.org/10.1037/emo0000017

Yakaboski, T., Perez-Velez, K., \& Almutairi, Y. (2018). Breaking the silence: Saudi graduate student experiences on a U.S. campus. Journal of Diversity in Higher Education, 11(2), 221-238. http://dx.doi.org/10.1037/dhe0000059

Zafar, S., \& Ross, E. C. (2015). Interreligious contact, attitudes, and stereotypes: A study of five religious groups in Canada. Canadian Journal of Behavioural Science / Revue canadienne des sciences du comportement, 47(1), 37-46. http://dx.doi.org/10.1037/a0036720 